\title{
Community-Oriented Policing: Hiring in the Spirit of Service
}

Leaetta M. Hough

The Dunnette Group, Ltd.

The authors of the focal article ask a very important question: "Baltimore Is Burning: Can I-O Psychologists Help Extinguish the Flames?" (Ruggs et al., 2016). The answer is yes, emphatically, yes. The applied science of industrialorganizational (I-O) psychology knows a great deal that can be brought to bear to help solve this real-world problem. As the title of this commentary indicates, personnel selection is one area that is highly relevant to this issue. Personnel selection is one of I-O psychology's specialty areas and is thought of by many around the world, including those in the U.S. legal system, as "owned" by I-O psychology. Other I-O specialty areas such as recruitment, training and development, onboarding/socialization, performance management, leadership, culture/climate, and culture/climate change also clearly have much to offer to help solve the problem. Others can address relevant research and practice in those areas; this commentary, however, is devoted to personnel selection. Revising a police department's hiring strategy is not a quick fix, nor is it, by itself, sufficient. Nonetheless, it is an important part of the package that I-O psychology has to offer.

This commentary describes research already done using wellestablished I-O principles and procedures to (a) define community-oriented policing, (b) identify person characteristics needed to perform communityoriented policing, and (c) identify existing evidence for selection/hiring strategies that are likely to enhance police effectiveness as defined by the community the police department serves. The work defining communityoriented policing was undertaken in the early 2000s and funded by the Community Policing Consortium of the U.S. Department of Justice's Office of Community-Oriented Policing Services. This commentary summarizes that work and highlights relevant research undertaken since then.

\section{Community-Oriented Policing Defined}

Descriptions of community-oriented police work are not typically found in formal job analysis reports. Instead, information about the activities and behaviors of community-oriented police behavior is found in summaries of focus group discussions about the behavior, skills, abilities, and attitudes of

Leaetta M. Hough, The Dunnette Group, Ltd., St. Paul, Minnesota.

Correspondence concerning this article should be addressed to Leaetta M. Hough, The Dunnette Group, Ltd., 370 Summit Avenue, St. Paul, MN 55012. E-mail: leaetta@msn.com 
community-oriented police officers and the role and goals of communityoriented law enforcement in enhancing safety in the community. Valuable information describing community-oriented police behavior is also found in literature describing problems police departments encounter as a result of their law enforcement duties. The following list was gleaned through focus groups with community groups, police officers, and their supervisors and leaders, as well as literature on community-oriented policing. Thus, the behavior/performance dimensions listed below are as much future oriented as past oriented. The performance dimensions, listed below, along with their definitions, characterize and define effective community-oriented police behavior (Hough, 2002, pp. 3-4):

- Integrity. Enforcing the law with fairness to all; accepting responsibility and accountability; responding to calls quickly; resisting opportunities to use one's badge, uniform, or authority for personal gain or ego trips; presenting evidence accurately and completely; acting courageously when needed; conducting oneself properly when off duty.

- Safety. Being careful and vigilant regardless of the routine, repetitive nature of the task at hand; being involved in few accidents; being mindful of own (and partner's) safety without overreacting to danger.

- Community relations. Getting to know the citizens: their concerns, values, habits, and families; establishing and maintaining partnership relationships with citizens and citizen groups; developing mentoring relationships with young people in the community; being respectful of people with backgrounds different from one's own; dealing with others in an interpersonally effective manner.

- Teamwork. Cooperating and working jointly with other officers, departments, divisions, agencies, or groups; keeping others informed of relevant information; having a good feel for what another person's actions are going to be without asking; backing up a partner or other officers.

- Judgment (situational, discretionary) and problem solving. Accurately assessing the situation and determining appropriate responses in all circumstances, including emergency, stressful, and dangerous situations as well as everyday situations both routine and unique; proactively solving problems and conflicts using an analytic approach that includes gathering information and acquainting oneself about the history leading up to the incident; helping those involved identify and solve the cause of the problem; using authority and force appropriately; using the "ready-gun" position sensibly; not letting stereotypes or one's own ego or emotions determine how to respond even when provoked or frustrated. 
- Patrolling, observing, and enforcing the law. Being alert to unusual circumstances or out-of-the-ordinary situations; knowing the "hot spots"; attending to details in one's surroundings; providing reasonable and proper enforcement of vehicular and traffic laws.

None of the dimensions listed above is new in defining effective police behavior. In community-oriented policing, the emphasis is different, with an orientation of service to the whole community motivating and underlying all of the behavior and dimensions of effective policing.

Specific tasks and job functions that police officers engage in are numerous and include maintaining order in the community, advising/assisting the public, working with others to reduce crime and address community concerns, detecting/investigating crimes, apprehending/arresting suspects, preparing for/presenting legal testimony, managing traffic, providing emergency assistance to the public, enhancing police-community relations, maintaining/improving job readiness, and documenting activities $\left(\mathrm{O}^{\star} \mathrm{NET}\right.$ OnLine, 2016; Spilberg \& Corey, 2014)

\section{Required Characteristics of Community-Oriented Police Officers}

Careful reading of the above performance dimensions, defining behaviors, and job activities/functions as well as a large amount of literature identifying characteristics of effective police officers indicates that the following characteristics are associated with effective community-oriented police work (Hough, 2002, pp. 5-6):

- Conscientiousness. Responsible; reliable; disciplined; rule abiding; organized; trustworthy; virtuous; honest; feels a sense of duty to other people; sets high standards; tries to do a good job; sets goals and strives to achieve them; perseveres; strives for competence; tries to do the right thing; gives $100 \%$ of his/her ability and skill versus unreliable; irresponsible; indolent; quitting; disrespectful of rules and regulations; rebellious; frivolous; does not expend undue effort; does not feel hard work is desirable; does not concentrate on or persist in the completion of the task at hand; impulsive; thrill seeking; unscrupulous.

- Emotional maturity and stability. Well adjusted; adaptive; even tempered; thinks clearly and maintains composure and rationality in situations of actual or perceived stress, danger, or threat; copes effectively with stress over time; good self-esteem; has control of his/her emotions without being rigid, high strung, or fragile versus unstable; angry; hostile; easily upset; loses his/her temper easily when provoked, challenged, or frustrated; easily threatened; goes to pieces in times of actual or perceived emergencies or stress; has a personality disorder. 
- Influential. Persuasive; optimistic; enthusiastic; energetic; vital; has the emotional energy needed to get things done; gains automatic respect versus lethargic, avoiding tasks requiring sustained effort; pessimistic; timid; silent; submissive; secretive; uneasy in social situations preferring instead to be or work alone.

- Amicability. Gets along with people over time and regardless of their background or similarity to him or herself; tactful; cooperative; warm; adds cohesiveness to a group; guileless; lives by the motto "do unto others as you would have them do unto you" versus contrary, defensive, critical; fault finding; touchy; alienated; spiteful, demanding; obstructive, creates friction; rigid.

- Service orientation. Likes to help others regardless of their background or similarity to him or herself; polite; personal; perceptive of others' needs; socially skilled; empathic; communicating accurately but pleasantly versus thoughtless; rude; tactless; imperceptive; socially inept; self-centered, narcissistic; selfish; authoritarian; prejudiced.

- Practical intelligence. Practical know how (tacit knowledge); ability to size up the situation and the available resources and improvise a solution; ability to reorganize and redirect effort to accomplish a task when necessary (for example, when something has changed or gone awry); ability to identify regularities and patterns in everyday situations; ability to identify causes and effects; common sense in handling everyday situations versus confused by information and situations; unable to solve everyday problems.

- Memory. Memory for people, faces, information, and events; working memory capacity versus forgetful; inattentive.

- Reading comprehension. Ability to read and comprehend written material. (Although the literature on community-oriented policing does not provide a direct link to this skill, it is included because of its usefulness in performing on-the-job and police academy activities.)

The list of skills, abilities, and personal characteristics needed for effective performance in community-oriented law enforcement settings differs somewhat from lists generated in more traditional law enforcement settings. The two most important differences are the emphases on service orientation and practical intelligence. Although practical intelligence is important in both settings, lists of officer requirements generated in traditional law enforcement settings focus more on intelligence required in school settings rather than in everyday life. Practical intelligence is clearly important in both settings. The above list recognizes its importance in actual job performance. In short, police officers who are conscientious, emotionally mature and stable, service oriented, amicable, and influential and who have good practical 
intelligence, memory (especially good working memory capacity), and reading skills are likely to perform well in community-oriented law enforcement settings and at the police academy. One of the requirements not listed above, but which should not to be overlooked, is physical fitness. Regardless of the type of policing, police officers need to be physically fit.

The California Peace Officer Standards and Training (POST) commission's analysis of characteristics required of effective police work incorporated a community-oriented policing perspective and is consistent with this list. That list includes, in order of importance: integrity, stress tolerance, anger control, decision making, courage/assertiveness, impulse/self-control, objectivity/tolerance, dependability/reliability, teamwork, worldliness/practical intelligence, influence/leadership, conformance to rules/regulations, adaptability/flexibility, interpersonal sensitivity, initiative/achievement motivation, positive attitude, acceptance of criticism, vigilance/attention to detail, and interpersonal interest/social concern (Spilberg \& Corey, 2014). With the exception of the assertiveness part of courage/assertiveness, these more specific characteristics are incorporated within the broader characteristics listed above. During the U. S. Department of Justice-funded project to identify and understand characteristics required for community-oriented policing, study participants (including police officers) stated that assertiveness easily bordered on aggressiveness, behavior that is often the antithesis of community-oriented policing. They preferred to use the term "Influential" and to emphasize hiring in the spirit of service rather than in the spirit of adventure.

\section{Evaluation of Evidence of Usefulness of Predictor Measures in Police Settings}

Validity and lack of adverse impact against minorities and women are important features of good assessment procedures. Measures that are used for selecting applicants for community-oriented police work should, at a minimum, be evaluated according to these factors.

\section{Criterion-Related Validity}

A variety of assessment procedures are available to assess the skills and abilities required to perform community-oriented policing effectively. They include simulations (work samples), situational judgment measures, interviews, peer evaluations, biodata including past relevant job performance, cognitive ability measures, and self- and other-report personality measures. Briefly summarizing the literature, (a) cognitive skills and abilities are useful predictors of police officer effectiveness; (b) noncognitive characteristics are useful predictors of police officer effectiveness; (c) cognitive and noncognitive characteristics are about equally predictive of police officer effectiveness; (d) measures of these skills and abilities differ in their likely 
adverse impact against minorities (these findings are described in the next section); and (e) cognitive and noncognitive measures used in combination increase the accuracy of prediction. (See the reference list for metaanalyses and individual studies documenting the validity of these various types of assessment procedures for predicting criteria relevant to police officers.)

The focal article highlights police officer use of lethal force against unarmed Black citizens and asks what the science and practice of I-O psychology can do to help address the issue. Recent research indicates that working memory capacity along with perceived threat is important in predicting shooting errors such as incorrectly shooting unarmed targets and a failure to shoot armed targets (Kleider \& Parrott, 2009; Kleider, Parrott, \& King, 2010).

Memory is a cognitive ability that is included in the list of individual characteristics that job/work analyses indicate are important for effective community-oriented policing. Yet, this variable is rarely included in police hiring procedures. When asked why not, I-O psychologists and test developers often declare it is impractical or too difficult to measure in most police testing settings. More research with working memory capacity is warranted, and more effort to include measures of working memory capacity is needed.

In addition, race stereotypes have been shown to be related to people claiming that they see a weapon when there is none. Moreover, Black (compared with White) target faces resulted in greater misidentification of objects, and Black targets are more likely to be shot than White targets. In addition, "shooter-bias" is more likely to occur under time pressure (Correll, Hudson, Guillermo, \& Ma, 2014; Correll, Park, Judd, \& Wittenbrink, 2002; Kahn \& Davies, 2011; Mekawi \& Bresin, 2015; Payne, 2001, 2006; Payne, Lambert, \& Jacoby, 2002; Plant \& Peruche, 2005).

Again, working memory capacity affects the automatic influences of stereotypes. Specifically, the executive functioning/executive attention that is measured by working memory capacity (Barrett, Tugade, \& Engle, 2004; Engle \& Kane, 2004) is considered the regulator of whether or not internal or external events capture the person's attention away from the task at hand. Thus, the combination of racial stereotypes (e.g., a Black face eliciting a racial stereotype), low working memory capacity, and the need to make a shoot/don't shoot decision increases the chances of a shooting decision error. The low working memory capacity (poor executive functioning/executive attention) allows the unconscious automaticity of a negative stereotype to interfere with the attention required to make an accurate decision quickly (Kane et al., 2007; McVay \& Kane, 2009, 2012a, 2012b; Payne, 2001, 2005, 2006; Payne, Shimizu, \& Jacoby, 2005). Working memory capacity is thus a 
measure that, if included in the hiring process, has potential for reducing some of the negative outcomes described in the focal article.

Another strategy that can be used during the hiring process to increase the chances that the police force consists of officers who are low in prejudice and racial stereotypes is to weight the assessment procedures that measure interpersonal competence (positive) and prejudice (negative) more heavily than other measures. Of course, training is another strategy for increasing the chances that the officers treat people of all ethnic groups and all types of backgrounds similarly.

\section{Adverse Impact of Hiring Procedures on African Americans and Latinos}

Adverse impact is calculated by comparing the hiring ratios of different groups and is a function of several factors. One of the important determinants is the mean score difference between two groups of interest (for example, African Americans and Whites, Latinos and Whites, men and women). The smaller the mean score difference between the two groups, the less likely adverse impact will occur. Choice of characteristics to measure in the hiring process, measurement method, measurement mode, and response format make a difference in mean score differences between groups (Courtright, McCormick, Postlethwaite, Reeves, \& Mount, 2013; Foldes, Duehr, \& Ones, 2008; Hough, Oswald, \& Ployhart, 2001; Huffcutt \& Roth, 1998; McDaniel, Psotka, Legree, Yost, \& Weekley, 2011; Pulakos \& Schmitt, 1996; Schmitt, Clause, \& Pulakos, 1996; Whetzel, McDaniel, \& Nguyen, 2008). Briefly summarizing the literature, (a) work/job samples/simulations, situational judgment inventories, and interviews can measure cognitive abilities resulting in smaller mean score differences between groups than written, multiple choice cognitive ability tests; (b) fluid intelligence tests (such as working memory capacity and reasoning ability tests) measure cognitive abilities with smaller mean score differences between groups than crystallized intelligence tests (such as knowledge tests); (c) noncognitive measures (such as personality inventories) show smaller mean score differences between groups than cognitive ability tests; (d) videobased measures show smaller mean score differences between groups than measures requiring the respondent to read items and response options.

\section{Discussion}

Ruggs et al. ask what the field of I-O psychology has to offer to help extinguish the flames that are burning across the United States as a result of what appears to many to be unequal treatment of African Americans by law enforcement officers. I-O psychology has already done significant research in the area of personnel selection and promotion that contributes to 
identifying and understanding police officers' characteristics that are important for effective community-oriented policing as well as how to measure those characteristics to increase minority representation on police forces in a way that is fair to all applicants and yields highly useful predictions of police officer performance. Needed is the commitment of (a) I-O psychologists to use what we know, (b) the citizenry of the United States to demand better police selection systems, and (c) police departments, unions, and hiring agencies and officials to implement better selection systems.

\section{References}

References marked with an asterisk indicate studies not specifically referenced in the text that report criterion-related validities relevant to police work.

*Aamodt, M. G. (1997, April). Relationship between cognitive ability and police performance: A metaanalysis. Paper presented at the 12th annual conference of the Society for Industrial and Organizational Psychology, St. Louis.

Barrett, L., Tugade, M. M., \& Engle, R. W. (2004). Individual differences in working memory capacity and dual-process theories of the mind. Psychological Bulletin, 130, 553-573.

*Barrick, M. R., \& Mount, M. K. (1991). The Big Five personality dimensions and job performance: A meta-analysis. Personnel Psychology, 44, 1-26.

*Black, J. (2000). Personality testing and police selection: Utility of the "Big Five." New Zealand Journal of Psychology, 29, 2-9.

*Borman, W. C., Penner, L. A., Allen, T. D., \& Motowidlo, S. J. (2001). Personality predictors of citizenship performance. International Journal of Selection and Assessment, 9, 52-69.

*Campion, M. C., Ployhart, R. E., \& MacKenzie, W. I. (2014). The state of research on situational judgment tests: A content analysis and directions for future research. Human Performance, 27, 283310.

Correll, J., Hudson, S. M., Guillermo, S., \& Ma, D. S. (2014). The police officer's dilemma: A decade of research on racial bias in the decision to shoot. Social and Personality Psychology Compass, 8(5), 201-213. doi:10.1111/spc3.12099

Correll, J., Park, B., Judd, C. M., \& Wittenbrink, B. (2002). The police officer's dilemma: Using ethnicity to disambiguate potentially threatening individuals. Journal of Personality and Social Psychology, 83(6), 1314-1329.

Courtright, S. H., McCormick, B. W., Postlethwaite, B. E., Reeves, C. J., \& Mount, M. K. (2013). A meta-analysis of sex differences in physical ability: Revised estimates and strategies for reducing differences in selection contexts. Journal of Applied Psychology, 98, 623-641.

Engle, R. W., \& Kane, M. J. (2004). Executive attention, working memory capacity, and a two-factor theory of cognitive control. In B. Ross (Ed.), The psychology of learning and motivation (Vol. 44, pp. 145-199). New York, NY: Academic Press.

Foldes, H. J., Duehr, E. E., \& Ones, D. S. (2008). Group differences in personality: Meta-analyses comparing five U. S. racial groups. Personnel Psychology, 61, 579-616.

*Frei, R. L., \& McDaniel, M. A. (1998). Validity of customer service measures in personnel selection: A review of criterion and construct evidence. Human Performance, 11, 1-27.

${ }^{*}$ Hirsh, H. R., Northrop, L. C., \& Schmidt, F. L. (1986). Validity generalization results for law enforcement occupations. Personnel Psychology, 39, 399-420.

Hough, L. M. (2002). Hiring in the spirit of service: Definitions, possibilities, evidence, and recommendations (Report No. DG-TR No. 27). St. Paul, MN: Dunnette.

*Hough, L. M. (2010). Assessment of background and life experience: The past as prologue. In J. Scott \& D. Reynolds (Eds.), Handbook of workplace assessment: Evidence-based practices for selecting and developing organizational talent (pp. 109-139). New York, NY: Wiley. 
*Hough, L. M., \& Johnson, J. W. (2013). Use and importance of personality variables in work settings. In I. B. Weiner (Ed.), N. Schmitt, \& S. Highhouse (Vol. Eds.), Handbook of psychology: Vol. 12. Industrial and organizational psychology (pp. 211-243). New York, NY: Wiley.

Hough, L. M., Oswald, F. L., \& Ployhart, R. (2001). Determinants, detection, and amelioration of adverse impact in personnel selection procedures: Issues, evidence, and lessons learned. International Journal of Selection and Assessment, 9, 152-194.

*Huffcutt, A. I., \& Arthur, W., Jr. (1994). Hunter and Hunter (1984) revisited: Interview validity for entry-level jobs. Journal of Applied Psychology, 79, 184-190.

Huffcutt, A. I., \& Roth, P. L. (1998). Racial group differences in employment interview evaluations. Journal of Applied Psychology, 83, 179-189.

*Joseph, D. L., \& Newman, D. A. (2010). Emotional intelligence: An integrative meta-analysis and cascading model. Journal of Applied Psychology, 95, 54-78.

Kahn, K. B., \& Davies, P. G. (2011). Differentially dangerous? Phenotypic racial stereotypicality increases implicit bias among ingroup and outgroup members. Group Processes \& Intergroup Relations, 14(4), 569-580.

Kane, M. J., Brown, L. H., McVay, J. C., Myin-Germeys, I., Silvia, P. J., \& Kwapil, T. R. (2007). For whom the mind wanders, and when: An experience-sampling study of working memory and executive control in daily life. Psychological Science, 18, 614-621.

Kleider, H. M., \& Parrott, D. J. (2009). Aggressive shooting behavior: How working memory and threat influence shoot decisions. Journal of Research in Personality, 43, 494-497.

Kleider, H. M., Parrott, D. J., \& King, T. Z. (2010). Shooting behavior: How working memory and negative emotionality influence police officer shoot decisions. Applied Cognitive Psychology, 24, 707-717.

*Lievens, F., Harris, M. M., Van Keer, E., \& Bisqueret, C. (2003). Predicting cross-cultural training performance: The validity of personality, cognitive ability, and dimensions measured by an Assessment Center and a Behavior Description Interview. Journal of Applied Psychology, 88, 476489.

*McCanlies, E. C., Mnatsakanova, A., Andrew, M. E., Burchfiel, C. M., \& Violanti, J. M. (2014). Positive psychological factors are associated with lower PTSD symptoms among police officers: Post Hurricane Katrina. Stress and Health, 30, 405-415.

*McDaniel, M. A., Hartman, N. S., Whetzel, D. L., \& Grubb, W. L. (2007). Situational judgment tests, response instructions, and validity: A meta-analysis. Personnel Psychology, 60, 63-91.

McDaniel, M. A., Psotka, J., Legree, P. J., Yost, A. M., \& Weekley, J. A. (2011). Toward an understanding of situational judgment item validity and group differences. Journal of Applied Psychology, 96, 327-336.

*McHenry, J. J., Hough, L. M., Toquam, J. L., Hanson, M. A., \& Ashworth, S. (1990). Project A validity results: The relationship between predictor and criterion domains. Personnel Psychology, 43, 335-354.

McVay, J. C., \& Kane, M. J. (2009). Conducting the train of thought: Working memory capacity, goal neglect, and mind wandering in an executive control task. Journal of Experimental Psychology: Learning, Memory, and Cognition, 35, 196-204.

McVay, J. C., \& Kane, M. J. (2012a). Drifting from slow to “D’oh!” Working memory capacity and mind wandering predict extreme reaction times and executive-control errors. Journal of Experimental Psychology: Learning, Memory, and Cognition, 38, 525-549.

McVay, J. C., \& Kane, M. J. (2012b). Why does working memory capacity predict variation in reading comprehension? On the influence of mind wandering and executive attention. Journal of Experimental Psychology: General, 141, 302-320.

Mekawi, Y., \& Bresin, K. (2015). Is the evidence from racial bias shooting task studies a smoking gun? Results from a meta-analysis. Journal of Experimental Social Psychology, 61, 120-130.

*Mount, M. K., Barrick, M. R., \& Stewart, G. L. (1998). Five-factor model of personality and performance in jobs involving interpersonal interactions. Human Performance, 11, 145-165.

*O'Brien, S. G. (1996). The predictive validity of personality testing in police selection: A meta-analysis. Unpublished master's thesis, University of Guelph. Guelph, Ontario, Canada. 
*Ones, D. S., Viswesvaran, C., \& Schmidt, F. L. (1993). Comprehensive meta-analysis of integrity test validities: Findings and implications for personnel-selection and theories of job performance [Monograph]. Journal of Applied Psychology, 78, 679-703.

O*NET OnLine. (2016, April 4). Summary report for 33-3051.01-Police patrol officer. Retrieved from http://www.onetonline.org/link/summary/33-3051.01

* Organ, D. W., \& Ryan, K. (1995). A meta-analaytic review of attitudinal and dispositional predictors of organizational citizenship behavior. Personnel Psychology, 48, 775-802.

Payne, B. K. (2001). Prejudice and perception: The role of automatic and controlled processes in misperceiving a weapon. Journal of Personality and Social Psychology, 81, 181-192.

Payne, B. K. (2005). Conceptualizing control in social cognition: How executive functioning modulates the expression of automatic stereotyping. Journal of Personality and Social Psychology, 89, 488-503.

Payne, B. K. (2006). Weapon bias: Split-second decisions and unintended stereotyping. Current Directions in Psychological Science, 15, 287-291.

Payne, B. K., Lambert, A. J., \& Jacoby, L. L. (2002). Best laid plans: Effects of goals on accessibility bias and cognitive control in race-based misperceptions of weapons. Journal of Experimental Social Psychology, 38, 384-396.

Payne, B. K., Shimizu, Y., \& Jacoby, L. L. (2005). Mental control and visual illusions: Toward explaining race-biased weapon misidentifications. Journal of Experimental Social Psychology, 41, 36-47.

*Peeters, M. A. G., Van Tuijl, H. F. J. M., Rutte, C. G., \& Reymen, I. M. M. J. (2006). Personality and team performance: A meta-analysis. European Journal of Personality, 20, 377-396.

Plant, E. A., \& Peruche, B. M. (2005). The consequences of race for police officers' responses to criminal suspects. Psychological Science, 16(3), 180-183.

Pulakos, E., \& Schmitt, N. (1996). An evaluation of two strategies for reducing adverse impact and their effects on criterion-related validity. Human Performance, 9, 241-258

*Pulakos, E. D., Schmitt, N., Dorsey, D. W., Arad, S., Hedge, J. W., \& Borman, W. C. (2002). Predicting adaptive performance: Further tests of a model of adaptability. Human Performance, 15, 299323.

* Roth, P. L., Bobko, P., \& McFarland, L. A. (2005). A meta-analysis of work sample test validity: Updating and integrating some classic literature. Personnel Psychology, 58, 1009-1037.

Ruggs, E. N., Hebl, M. R., Rabelo, V. C., Weaver, K. B., Kovacs, J., \& Kemp, A. S. (2016). Baltimore is burning: Can I-O psychologists help extinguish the flames? Industrial and Organizational Psychology: Perspectives on Science and Practice, 9(3), 525-547.

*Sarchione, C. D., Cuttler, M. J., Muchinsky, P. M., \& Nelson-Gray, R. O. (1998). Prediction of dysfunctional job behaviors among law enforcement officers. Journal of Applied Psychology, 83, 904912.

*Schmidt, F. L., \& Hunter, J. E. (1998). The validity and utility of selection methods in personnel psychology: Practical and theoretical implication of 85 years of research findings. Psychological Bulletin, 124(2), 262-274.

Schmitt, N., Clause, C. S., \& Pulakos, E. D. (1996). Subgroup differences associated with different measures of some common job-relevant constructs. International Review of Industrial and Organizational Psychology, 11, 115-139.

Spilberg, S. W., \& Corey, D. M. (2014). Peace officer psychological screening manual. West Sacramento, CA: California Commission on Peace Officer Standards and Training (POST) Standards, Evaluation, and Research Bureau.

*Verive, J. M., \& McDaniel, M. A. (1996). Short-term memory tests in personnel selection: Low adverse impact and high validity. Intelligence, $23,15-32$.

Whetzel, D. L., McDaniel, M. A., \& Nguyen, N. T. (2008). Subgroup differences in situation judgment test performance: A meta-analysis. Human Performance, 21, 291-309. 